\title{
Ricoeur on time: From Husserl to Augustine
}

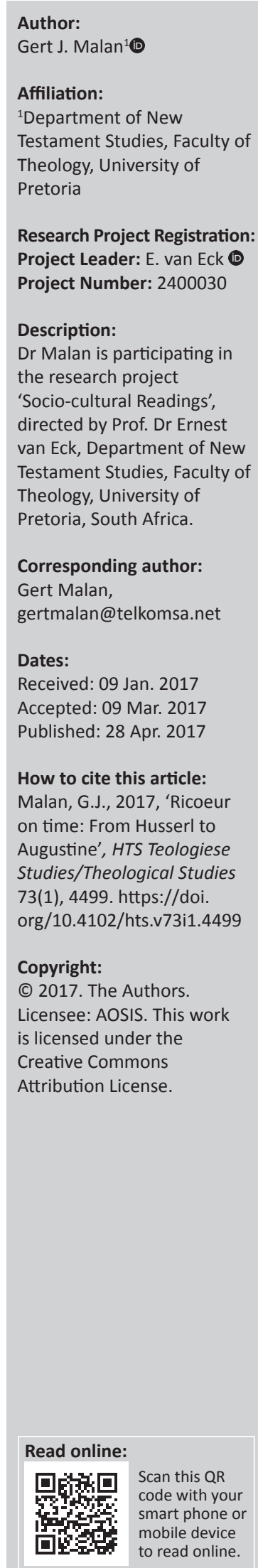

The development in Ricoeur's concept of time did not receive as much attention as his move from eidetic to hermeneutic phenomenology and his Time and Narrative, with which it coincided. This paper attends to the lacuna, specifically departing from Ricoeur's Husserlian eidetics and moving towards the influence of Augustine's discussion of the main aporias of time. Initially, Paul Ricoeur's philosophic approach can be described as a Husserlian eidetic phenomenology, which influenced the way in which he understood time. This changed somewhat when Ricoeur moved from eidetic to hermeneutic phenomenology. Ricoeur has developed his understanding of the concept of time since his initial writings up to the end of his academic career of 70 years. This article focusses on Ricoeur's initial eidetic approach in Freedom and Nature and, in more existential terms, in Fallible man, but also focusses on the initial phase of his turn to hermeneutics in Volume 1 of Time and Narrative with his exposition of Augustine's views on time. His eidetic approach stems from his appreciation for and extension of the work of Husserl, Marcel and Kant, while he also drew much from Heidegger and Gadamer after his hermeneutic turn. His initial arguments on the hermeneutic phenomenology of time flow from Augustine's discussions of the aporias of time. The later extension of his understanding of time to include emplotment was a logical next step.

\section{The movement in Ricoeur's phenomenological approach}

Much has been written on Ricoeur's move from eidetic to hermeneutic phenomenology and his three-volume work Time and Narrative, but the coincidental development in Ricoeur's conception of time did not receive as much attention, as can be deduced from the list of references based on searches of the topic. This paper attends in part to this lacuna in a quantitative manner, describing specifically how Ricoeur's departure from Husserlian style eidetics and his move towards hermeneutics via the influence of Augustine's discussion of the main aporias of time expanded his understanding of time. The further developments in Ricoeur's understanding of time will be attended to in a future study, all forming part of a larger hermeneutic project (see footnote 1). This study concludes by showing the next logical step in the development of Ricoeur's understanding of time.

Paul Ricoeur's understanding of time developed from his Husserlian phenomenological style philosophy of the will. ${ }^{1}$ As Ricoeur aptly stated, 'I began my first work, on the philosophy of the will, as a disciple of Husserl' (Ricoeurin Dowling 2011:Appendix). Ricoeur's fresh phenomenological approach was a revision of the idealist and objective approach that Husserl proposed as foundation for science (Stiver 2012:5). Phenomenological method suspends all questions of an external world while paying careful attention to an object that exists in and for consciousness (Dowling 2011:Chapter 2). It attempts to provide accurate but not jargon-laden descriptions of the essence of various experiences. The influence of his three mentors, Edmund Husserl, Gabriel Marcel and Immanuel Kant, can be seen in Ricoeur's initial eidetic phenomenological approach (Lowe 2002:vii-xxxii). Eventually Ricoeur's hermeneutical phenomenology has built on and transformed the German phenomenology of Husserl, Heidegger and Jaspers in a profound and significant way (Landridge 2004:243; Thiselton 2006:238). His views on the effect and experience of time was an interwoven facet of his philosophy in both phases of his phenomenological career but received more intense focus after his 'turn to hermeneutics' (Pellauer 2007:42). After his hermeneutic turn, his ideas on time drew heavily from Heidegger and Gadamer (Landridge 2004:243).

1.See Ricoeur's dissertation titled: 'Freedom and Nature: The Voluntary and Involuntary' (Ricoeur [1950] 1966).

Note: This article forms part of a larger hermeneutics project proposing a broad-based, multi-disciplinary approach, which can be utilised for theological hermeneutics, while also investigating the origins of its components and their various interrelationships. Hermeneutically significant aspects are studied from the fields of mythology, symbolism, metaphor theory, psychology and psychoanalysis, sociology of knowledge, anthropology, neuroscience and philosophy, especially phenomenology, existentialism and philosophical hermeneutics (see Malan 2016a; 2016d). Ricoeur's hermeneutic contributions are significant in several regards, for instance, metaphor theory, interpretation of myths and symbols, narrative theory, linguistics and his understanding of time (Malan 2016b; 2016c; 2016d). Future studies will include Ricoeur's views on narrative time and emplotment, the fictive experience of time, historical time, the hermeneutic and the narrative arc and the interpretation of history, historical intentionality and his proposal for a hermeneutics of historical consciousness, to name but a few. 
This study investigates how the context of Ricoeur's initial Husserlian phenomenology followed by his turn to hermeneutics influenced and broadened his understanding of time, which can be utilised for theological hermeneutics.

\section{Time in Ricoeur's eidetic phenomenology}

\section{A philosophy of the will}

His dissertation entitled 'Freedom and Nature: The Voluntary and the Involuntary' (Ricoeur [1950] 1966) was meant to be the first of a three-volume philosophy of the will. The first volume was devoted to the eidetics of the will, the second and third volumes dealt with empirics and poetics (Kohak 1966:xi). His first goal was to grasp the reciprocity of the voluntary and involuntary in human existence which makes freedom meaningful. He immediately acknowledged the inherent limits to such a phenomenological approach, namely human existence being embodied and temporal (Ricoeur [1950] 1966:37). ${ }^{2}$ His 'something like' an eidetic (exceptionally vivid and detailed) approach ${ }^{3}$ focussed on immediate apprehension of essences abstracted from the unfolding of action over time by dividing it into atemporal stages. ${ }^{4}$ This method resulted in the problem of making sense of the overall unity in time of these separate stages (Pellauer 2007:5).

His phenomenology started by differentiating between 'deciding' and voluntary motion, concluding that what separates them is a conceptual rather than a temporal interval. Decision, as a personal act, is characterised by an expectation of a 'future perfect' of what will have come. As such, the future and time are conditions of action (Pellauer 2007:14-15; Ricoeur [1950] 1966: 48-55). Ricoeur was influenced by the more embodied approach to phenomenology of MarleauPonty's Phenomenology of Perception (1945) (Ricoeur [1950] 1966:231-235) and Gabriel Marcel's approach tying his rediscovery of incarnation ${ }^{5}$ to a bursting of thought by object, to a conversion from 'objectivity' to 'existence' and from 'problem' to 'mystery' (Ricoeur [1950] 1966:15-17). This is reflected boldly in Freedom and Nature, in which Ricoeur stressed how the will always involves the body (cf. Ricoeur [1950] 1966: 8-17, 34-134, 201-338). Ricoeur concludes his eidetics of the will by referring to freedom as being uniquely human and thus motivated, experienced in time and place, based on incomplete knowledge and therefore always involving risk. It is a willing but not a creative freedom and involves decision, effort and consent. As such, it is an incarnate 2.With his phenomenological approach, Ricoeur seeks to regain the 'presence of the
body', which lends the concepts of motive and quality of existence, as well as temporality as 'lived duration'.

3.An eidetic phenomology uses the concept of eidetic reduction in order to bracket al incidental meaning to reveal the possible invariate aspects of experience. Iconic reduction attempts to offer iconic images of a phenomenon as intimations of meaningfulness. It is not a simplification, fixation or contraction of the world into fully resolved concepts but makes the world appear in its full ambiguity, irreducibility, contingency, mystery and ultimate indeterminacy (Phenomenology Online 2011).

4.'The eidetic approach forces us to describe these relations without reference to time or, if you wish, in instantaneous segments cut out of the flux of consciousness (Ricoeur [1950] 1966:37).

5.Marcel's central intuition, described as 'incarnation', expresses the ultimate ontological unity of man's being-in-the-world, leading Marcel to wrestle with the problem of describing the polar structure of the ultimate identity of subject and object (Kohak 1966:xiii). freedom, which represents its limits and grandeur (Kohak 1966:xxviii-xxix).

\section{Consciousness of fault}

With Fallible Man, on the other hand, the influence of existentialist thinkers such as Heidegger and Sartre's appropriation of phenomenology can be seen. In this second phenomenological work, he characterised the self in existential terms, namely as poised between heaven and earth, being rooted in the body and yet transcending it through imagination. As man is pulled in many directions, the result is the human tendency toward error and evil. He concluded that such inherently irrational acts could not be rationally described in terms of essences, but could only be depicted through symbol and myth. This resulted in his following work, The Symbolism of Evil, which appeared with Fallible Man as a companion volume. There his move to hermeneutic phenomenology becomes apparent (Stiver 2012:5; see also Kohak 1966:xxix-xxx; Simms 2002:15-16).

Already the traces of a movement to hermeneutics in Fallible Man can be seen in Ricoeur's shift to existential depictions of the human condition, especially his views on the concept of fault. In his preface to Fallible Man, Ricoeur ([1960] 2002:xlviixlviii) argues the limits of an ethical vision by referring to the work of Jean Nabert. The effect of temporality is shown in Nabert's conclusion that the avowal of fault is, at the same time, the discovery of freedom. 'Fault' and 'freedom' are called temporal 'ecstasies', ${ }^{6}$ entwined in a profound unity of their past and appearing in their future primarily in the consciousness of fault. The distressed and remorseful contemplation of the past is combined with the certitude of possible future regeneration through repentance, which is a re-emergence through memory. Thus, in the consciousness of fault, the future attempts to encompass the past as selfdiscovery realises recovery. In the joining of the temporal ecstasies of the past and the future in the core of freedom, the consciousness of fault reveals the total and undivided causality of the self over and above its individual acts. The discovery of fault shows a discrepancy between the demand for wholeness and the acts that disappoint this demand. In this consciousness of fault, Nabert (1943:16) detects an obscure experience of non-being. It is a kind of reverse participation. Any act of the self does not alone create all the non-being that is in fault, but determines it and makes it its own (Ricoeur [1960] 2002:xlviii).

\section{Perception and expression}

Ricoeur ([1960] 2002:18-24) also relates time to perception, specifically in his discussion on the finite perspective in Fallible Man. He associates perception with the presence of things and our possible reaction to them. We can simply receive their presence by giving ourselves intuitively to their existence, or we can dominate their presence by thinking about them and in this way determine their meaning for us with articulate phrasing (Ricoeur [1960] 2002:19). 6. From the French 'extases', and relates to Heidegger's concept of 'Ekstasen' (Heidegger [1927] 1996:32). 
Our perception is always a bodily perception, which Ricoeur describes as openness, as being '... open onto ([1960] 2002:19)', which makes the body a mediator between a person and the world (see Figure 1 and Figure 2).?

This leads to a limitation of bodily perception, namely that it is always from a specific point of view, meaning a certain angle at a given time. On the other hand, bodily perception of time implies a definite correlation between time perception and formation of personal identity (Atkins 2000:329-349). Its perspectival nature limits perception to only one side of an object at any given moment, and the unity of the object is never more than the presumed unity of flux of these silhouettes (Ricoeur [1960] 2002:21). This inadequacy of perception results in precepts ${ }^{8}$ being cancelled or confirmed in the sense that it may reveal itself as different from what was initially perceived. The effect of time is that the same object unravels into other profiles, into the "and then ... and then" of the object's appearing' (Ricoeur [1960] 2002:21). The dimensions of space and time dominate our bodily perceptions and points of view resulting in life being a series of perceptions:

From the moment I am 'brought into the world' I perceive this world as a series of changes and re-establishments starting from this place which I did not choose and which I cannot find in my memory. (p. 23)

As we cannot recall the event in time and place of our birth, it is mainly an event for others and not the primordial starting point from where we recall all our 'heres'. On the contrary, from the here and now (hic et nunc) as absolute

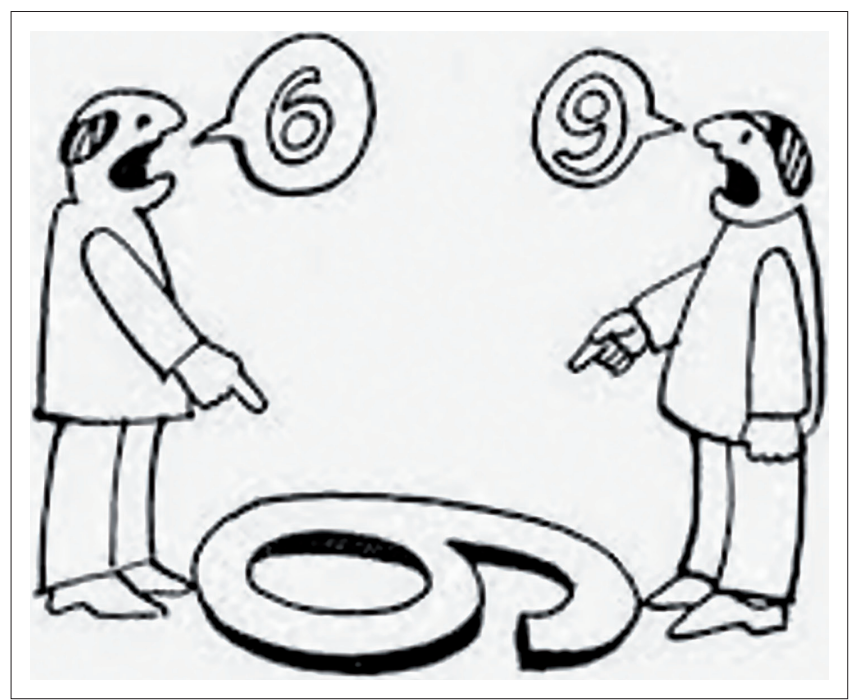

Source: Pinterest.com

FIGURE 1: Perception as bodily and from a certain viewpoint and time.

7.Ricoeur concurs with Kant's 'Refutation of Idealism' in Critique of Pure Reason (Kant [1781] 1984:170-177) about bodily mediation of perception thanks to the openness of the body to the world. In this sense the world is not the boundary of our existence but its correlate. Kant reasons from the theorem that the simple but empirically determined consciousness of my own existence proves the existence of external objects in space. The concept of time plays an important part in his proof of the objects in space. The concept of time plays an important part in his proof of the theorem. Kant argues that '... the determination of my existence in time is possible only through the existence of real things external to me...' and concludes that '... the consciousness of my existence is at the same time an immediate consciousness of other things without me' (Kant [1781] 1984:171).

8.A precept is the object of perception as opposed to the perceiving act or the subject of perception (Ricoeur [1960] 2002:20 footnote 1). here, we lose track of our earliest 'heres' and borrow them from the memories of others. Our births are therefore not among the 'heres' of our lives and therefore not their source (Ricoeur [1960] 2002:24). This underlines the finiteness of our perceptions and points of view.

Time should also be considered when we express our perceptions to others. The finiteness of our momentary perceptions and points of view is transcended (Ricoeur uses the term 'transgressed') when we communicate our perception from a certain point of view. To express our view is to signify and thus to intend. The transgression occurs when we anticipate and speak about the whole of something which we know but have only viewed one side of it from our own point of view. When speaking about it, and thus intending, we signify the perceived presence in the living present, which is the 'present of the presence' (Ricoeur [1960] 2002:27). As our utterance is saturated with presence, it is always accompanied by fulfilment, namely of the intention behind speaking about it at a given time (Ricoeur [1960] 2002:24-27).

\section{Transcendental imagination}

Perspective (sensory perception as letting objects appear) and its transgression through expression (as the intellectual determination of objects) are the two poles of the single function of our (bodily) openness. The image of openness recalls the image of clarity or light as it is found in Platonic and Cartesian traditions. The image of light suggests a medium in which we see, as we do not see the light but in the light. As such, light is both the space of appearance and a space of intelligibility, of appearance (and perception) and expressibility (and determination). With this metaphor, Ricoeur expressed the presuppositions of the Kantian problem of pure imagination, namely the synthesis of the rules (categories) of expressibility and the conditions of appearance (perception, intuition) in the 'transcendental imagination' (Ricoeur [1960] 2002:40-41; 1981:228-247).

Between the polarity of perception and expression, of intellect and senses, a third, mediating concept is needed, which is pure (meaning: void of all empirical content) and yet both intellectual and sensible. As mediator, the transcendental imagination does not exist for itself but for a synthesis of perception and expression while the imaginative synthesis is for itself obscure, an enigma:

\footnotetext{
... an art concealed in the depths of the human soul, whose real modes of activity nature is hardly likely ever to allow us to discover, and to have open to our gaze. (Kant in Ricoeur [1960] 2002:41; also Stiver 2012:74-75)
}

In order to solve this enigma, Ricoeur again refers to Kant, who resorted to the transcendental determination of time (Kant [1781] 1984:47-53). Time is the resolution of the enigma of transcendental imagination because time is the condition of all lived diversity, of every surprise, encounter, innovation and appearance and of all incoherence. As such, time is not only essentially distended (disconnected) and therefore homogenous with phenomena but also determinable in the 

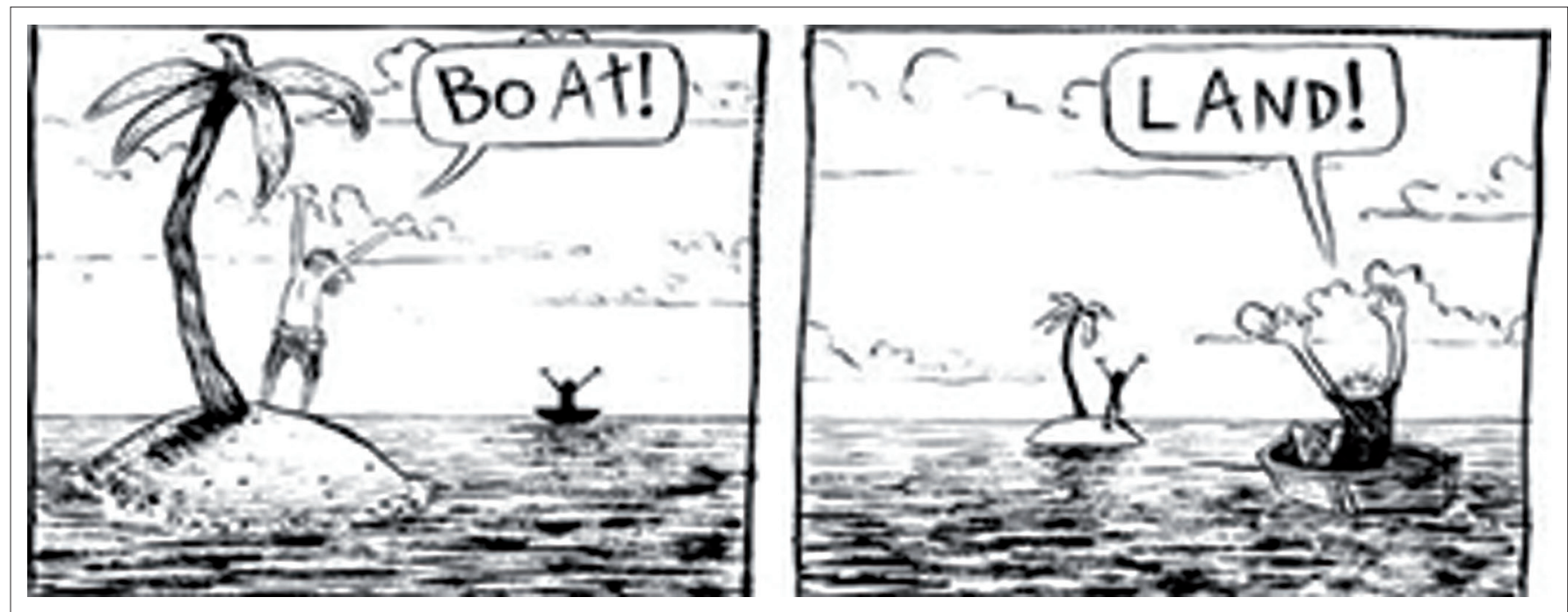

Source: Pinterest.com

FIGURE 2: Perception as bodily and from a certain viewpoint and time.

highest degree to understanding as all categories are rooted in understanding in the form of schemata (Ricoeur [1960] 2002:42). The theory of schematisation determines time; thus, each category makes itself intuitive and receives a dimension full of imagery. In our apprehension of this intuition, we generate time as a series of successive representations. Time is therefore that mediating order, homogenous with sense and intellect, with perception and expression and in this sense, time is also the coincidence of 'manifold' and 'series' (Ricoeur [1960] 2002:42; see also Verhoef \& Van der Merwe 2015:202-207).

Time is also determinable in terms of other relations and can be experienced as empty or filled, or degrees thereof. We can also consider time as an ordering function, for example something follows another, or persists in time, or coexists with something else within a reciprocal relationship. At the same time, and paradoxically so, time is both the form of all diversity but time is also determined by our understanding and its categories. In this way, time scatters and orders, diversifies and unifies, as Augustine called it: distentio and intentio animi (Ricoeur [1983] 1990:5). Thus time is the unity of this duality, the common root of understanding and sensibility (Ricoeur [1960] 2002:42). Space and time can be reduced to unity only by means of the empirical imagination's power of synthesis which associates perceptions. Transcendental imagination in the same sense mediates a synthesis of understanding and sensibility, expression and perception, meaning and appearance through consciousness. This consciousness is not self-consciousness but '... the formal unity of consciousness in the synthesis of the manifold of representations' (Ricoeur [1960] 2002:45; Verhoef \& Van der Merwe 2015:202). But this formal unity is only the condition of possibility, a unity in intention. Consciousness therefore spends itself in founding the unity of meaning and presence in the object, not merely as consciousness of a person in itself and for itself, but for anyone and everyone (Ricoeur [1960] 2002:45-46). ${ }^{9}$

9.In this sense, Ricoeur viewed historiography as works of the imagination (Stiver 2012:79).

\section{Time and Ricoeur's hermeneutic turn}

Ricoeur made a transition from eidetic to hermeneutic phenomenology and the philosophy of language, leading to his study of symbol, myth, metaphor and narrative (Pellauer 2007:42; also Landridge 2004:243; Stiver 2012:5, 9-11). Throughout his career, however, Ricoeur showed a passion for the nature of the self, the subject and personal identity, which can be described in phenomenological terms as subjectivity, which is more appropriate to the eidetic phenomenology. This remained constant, even as his focus eventually shifted to political philosophy. Ricoeur's sustaining of the 'eidetic moment' through the various stages of his career is distinctive and in his stalwart defence of temporality and subjectivity reveals that the idea of a philosophy of the will never left him and that insights from his past work did not become redundant but gained broader and deeper insight (Rasmussen 2007:196-202).

\section{'Time and Narrative'}

With his three-volume work Time and Narrative (Ricoeur [1983] 1990; [1984] 1990; [1985] 1990), Ricoeur proposes a series of arguments concerning the nature of time in order to highlight the continuity and discontinuity between phenomenological and objective time (Atkins 2002:388). He concerned himself with the experience of time and offered narrative as mediating between the concepts of chronological clock time with experienced, existential time (Stiver 2012:78). In the first of these three volumes, Ricoeur reasons from the one presupposition that commands both the structural identity of the narrative function and the truth claim of every narrative work, namely the temporal character of human experience. The world unfolded by a narrative work is always a temporal world:

Time becomes human time to the extent that it is organised after the manner of a narrative; narrative, in turn, is meaningful to the extent that it portrays the features of temporal experience. (Ricoeur [1983] 1990:3) 
This circular thesis is examined by referring to the theory of time in Book 11 of Augustine's Confessiones and to the theory of plot in Aristotle's De Poetica. ${ }^{10}$

\section{Augustine on time}

It is startling that the church father Augustine, an expert in rhetoric, persuasive writing, theology and philosophy in his Confessiones suddenly shifts from descriptions of his personal failings and relationship with his parents to a physicist's discussion of the nature of time (Nordlund 2015:222). ${ }^{11}$ Ricoeur especially refers to Augustine's views on time as stated in Book XI of his Confessiones.

\section{The being and nonbeing of time}

Augustine offered at least nine distinct views on the nature of time (Carter 2011:301). Augustine's struggle with the major aporia ${ }^{12}$ of time, namely its measurement, is encompassed by the even more fundamental aporia of the being and nonbeing of time. The phenomenology of time emerges from the ontological question: 'What then is time?' The sceptical argument reasons that time has no being since the future is not yet, the past is no longer and the present does not remain (Jansen 2015:1). ${ }^{13}$ Yet we speak of time as having being, saying that things to come will be, and past things were, and present things are passing away. Thus language usage provisionally provides resistance to the thesis of nonbeing (Ricoeur [1983] 1990:7) (see Figure 3).

But language itself is put into question, as it cannot answer the questions of how time comes about and what it is. As Augustine aptly illustrated:

\begin{tabular}{|l|l|}
\hline Sceptic's argument: & $\frac{\text { Resistance of language: }}{\text { being of time }}$ \\
\hline $\begin{array}{l}\text { Future } \\
\text { (not yet) }\end{array}$ & Future: Things to come will be \\
$\begin{array}{l}\text { Present } \\
\text { (does not } \\
\text { remain) } \\
\begin{array}{l}\text { Past } \\
\text { (is no longer) }\end{array}\end{array}$ & $\begin{array}{l}\text { Present: Present things are } \\
\text { passing away }\end{array}$ \\
\hline
\end{tabular}

Source: Author's own work

FIGURE 3: The paradox of time: Sceptic's argument versus resistance of language: nonbeing versus being of time.

10.It is important to note that Augustine inquires into the nature of time without apparent concern for grounding his inquiry on the narrative structure of his autobiography in the preceding nine books of the Confessiones. Aristotle constructs his theory of dramatic plot without paying attention to the temporal implications his theory of dramatic plot without paying attention to the temporal implications
of his analysis, leaving the problem of analysing time to the Physica. In this sense Augustine and Aristotle offer two points of access, independent of one another, to the circularity of the above thesis (Ricoeur [1983] 1990:vii;3-4).

11.Nordlund (2015:230-234) relates Augustine's ideas on measuring time using 'time slices' with modern physics' views.

12.'Aporia' refers to an impasse, difficulty or puzzlement. In philosophy it refers to a puzzlement occasioned by the raising of philosophical objections without any
proffered solutions; a difficulty in establishing the theoretical truth of a proposition. in rhetoric it refers to a rhetorically useful expression of simulated or real doubt about what to say or do (Dictionary.com 2011).

13. Hesitation when speaking about the existence of time (e.g. Aristotle and Henri Bergson) stems from the idea that the three elements of time, namely past, present and future are fleeting. The past no longer exists, the present is slipping by quickly and the future is not yet there (Jansen 2015:1)
What then is time? I know well enough what it is, provided that nobody asks me; but if I am asked what it is and try to explain, I am baffled. (Augustinus Hipponensis [401] 2012: Book XI, quoted by Ricoeur [1983] 1990:7)

Thus, the ontological paradox opposes language both to the sceptical argument and itself. The positive quality of the verbs 'to have taken place', 'to occur', 'to be', cannot be reconciled with the negativity of the adverbs 'no longer', 'not yet', 'not always', begging the question how time can exist if the past is no longer, if the future is not yet and if the present is not always (Ricoeur [1983] 1990:7). Such is the paradox of the being and nonbeing of time, which leads to the paradox of measurement as it is impossible for us to measure anything that does not exist.

Language may offer that only of the past and future can be said that they are long or short, even more accurately that the future shortens and the past lengthens, but again the 'how' of it eludes language. Only of the present can be said that it is an indivisible instant, pointlike, with no duration (Carter 2011:304 referring to De Musica (Augustinus Hipponensis [391] 1938). The only argument against the nonbeing of the past and future seems to be our experience, articulated in language, namely of what we say and do with regard to them. We recount (discern) the past and predict (foresee) the future. This leads to Augustine's thesis of the threefold present (Ricoeur [1983] 1990:7-10).

Reasoning from the seemingly naïve question of where the past and future can be found, Augustine concludes that wherever they are, it is only in being present that they are (exist). But how? Recounting (narrating the past) implies an impression (image) on the memory, while predicting the future implies expectation. The present (presence, being) of the past resides in the memory, the present is available by direct perception and the present (presence or being) of the future lies in expectation (Carter 2011:307; Meyer-Baer 1953:229) ${ }^{14}$ Expectation or prediction is analogous to memory as an impression which already exists in the sense that it precedes the event that does not yet exist (Ricoeur [1983] 1990:10-11).

\section{The measurement of time}

The proposition that we measure time as it passes becomes an aporia, as what actually passes is the present, of which was claimed that it has no extension. The answer to this aporia is given with recourse to the threefold present and quasi-spatial language: passing is interpreted as being in transit, as passing through, thus time passes from the future through the present into the past. This idea of transit confirms time being measured relative to some measurable period and that all relations between intervals or time are in relation to a given period, leaving the problem of time as not extended in space, as momentary, thus, without duration and immeasurable (Ricoeur [1983] 1990:13; also Manning et al. 2013:236-237). 
In order to solve this enigma, Augustine rejects the cosmological solution ${ }^{15}$ in favour of the mind's (soul's) ${ }^{16}$ solution of the threefold present (the soul or intellect expects, perceives and remembers) (Meyer-Baer 1953:229) for the basis of extension and measurement. Arguing from the idea of extension (distentio) and the enigma of time as being which lacks being and the extension of a thing that has no extension, Augustine suggests the extension (distentio) is of the mind itself (Ricoeur [1983] 1990:16). What remains is to conceive of the threefold present as distentio in order to measure time as it passes. ${ }^{17}$

\section{Intentio and distentio}

To reach this goal Augustine returns to the idea of measuring the flow of time as it is passing in order to show the multiplicity of the present. Is there a way to measure time passing, both when it has ceased and while it continues? Augustine uses the example of reciting by heart a hymn's verse with long and short syllables that alternate, thus introducing memory, retrospection and comparison into the equation. ${ }^{18}$ Thus, while reciting, though the sound passes, the syllables exist as impressions retained in memory and those to be pronounced are signs in expectation. What is measured is not the spoken syllables that do not exist anymore. What is measured are the syllables that remain in memory. The important verb is no longer 'to pass' but 'to remain', resolving the enigma of the being and non-being of time, as well as the enigma of measuring that which has no extension. It is important to note that with this example, the present changes. It is no longer a point, nor a point of passing, but a present intention (intentio), as the person reciting is intending to pronounce the syllables. Viewed in this way, the present is not travelled through, but the present is someone's attentive mind relegating the future to the past so that the past increases as the future diminishes until it is entirely absorbed into the past. In this scenario there would be no future diminishing into the past without a mind to regulate the process while preforming the three functions of expectation, attention and memory (Meyer-Baer 1953:229). Thus, the future which it expects, passes through the present which is attended to, and into the past, which it remembers. While the future and the past are in the expecting and remembering of images in the mind (i.e. the extension of time), ${ }^{19}$ the present is again reduced to a point, expressing the present's lack of extension, while admitting that the mind is still attentive (Ricoeur [1983] 1990:17-19).

\footnotetext{
15.According to Aristotle, time is constituted by and should therefore be measured by the movement of the heavenly bodies, which Aristotle views as constant. Augustine accepts that the movement of heavenly bodies might vary, might accelerate or
slow down, or even cease to move. Time should therefore have to be measured by something other than movement. Thus Augustine speaks of days, hours and minutes without recourse to a cosmological reference (Ricoeur [1983] 1990:14).

16. Augustine refers to the 'time of the soul' (Dowling 2010:149; Augustinus Hipponensis [401] 2012 Book XI).

17.According to Carter (2011:311) Augustine views time as indirectly measured in a special type of space, namely the extended space of memory.

18.Meyer-Baer (1953:229-230) views Augustine's example as ontologic and his view on the present extremely differentiated, thus surpassing his contemporaries.

19.Augustine was probably the first philosopher to propose that past and future could be seen as equivalent entities that exist as long as they are present in ou consciousness (Manning et al. 2013:239).
}

Distention (distentio) lies in the contrast between the three tensions, namely, expectation, memory and attention. ${ }^{20}$ It is the shift or division in the three modalities of action: of expectation, memory and attention, as well as the division of the attention between the act of reciting (acting), memory (looking back) and expectation (looking forward) which extend (Ricoeur [1983] 1990:19-20; also Humphries 2009:77; Carter 2011:310-311). This still leaves us with an enigma: how can memory and expectation be measured without points of reference and what independent access do we have to the extension of the mind's (soul's) impressions? Even more enigmatic: Augustine resolves the aporia of the measurement of time by reverting to the soul (mind) distending (distentio) itself, even as it engages (intendio) itself,;, 21 in other words: both time and its principal measurement are in the mind (soul) (Ricoeur [1983] 1990:21-22) (see Figure 4).

\section{Time in contrast with eternity}

Yet the full sense of distentio seems to be lacking that which only the contrast with eternity as a different order can provide (Humphries 2009:78-79). Eternity places all speculations about time within the horizon of a limiting idea, namely of what time is not. ${ }^{22}$ Eternity also intensifies the experience of distentio (extension) and calls on this experience to surpass itself by moving towards eternity rather than be fascinated by rectilinear time. Augustine reasons from the first creation story in Genesis and views creation as that which has a before and an after and is therefore subject to change and variation, while eternity is something that exists that was not created and is not subject to variation or change. On the creation $e x$ nihilo by God's spoken word, Augustine argues that in this Word all is uttered at one and the same time, yet also eternally. If not, God's Word would be subject to time and change and not truly eternal or immortal (Ricoeur [1983] 1990:22-24).

Eternity, in Augustine's view, is forever still, meaning that nothing moves into the past, in contrast with time, which is never still, with constant movement from future to past. In

\begin{tabular}{|c|c|c|}
\hline $\begin{array}{l}\text { Distentio (the mind } \\
\text { extends across time) }\end{array}$ & $\begin{array}{l}\text { Future } \\
\text { (present as } \\
\text { expectation) } \\
\text { Present } \\
\text { (present as direct } \\
\text { perception) }\end{array}$ & $\begin{array}{l}\text { Intentio } \\
\text { (a person's } \\
\text { present intention } \\
\text { and engagement) }\end{array}$ \\
\hline & $\begin{array}{l}\text { Past (present in } \\
\text { memory) }\end{array}$ & \\
\hline
\end{tabular}

Source: Author's own work

FIGURE 4: Augustine's threefold presence, intentio and distentio.

20.Humphries (2009:77) describes pure distentio as signifying a created (mind independent) intrinsically sequential, non-extended reality of time, concluding that it is non-human, concurring with Augustine that distentio should be that of the animus [soul or intellect] and thus essentially human.

21. Ricoeur views this as 'Augustine's inestimable discovery' that, ... by reducing the extension of time to the distension of the soul, to have tied this distension to the slippage that never ceases to find its way into the heart of the threefold present between the present of the future, the present of the past, and the present of the present. In this way he sees discordance emerge again and again out of the very concordance of the intentions of expectation, attention and memory (Ricoeur [1983] 1990:21).

22.Time passes as a succession, while eternity exists as a nunc stans (Humphries 2009:79). 
eternity, thus, all is present at once (Humphries 2009:79). Eternity should therefore be compared to the threefold present and viewed as a present without past or future. Time was created; eternity was before creation. ${ }^{23}$ To the question of what God made before creation, Augustine responds that God made nothing. Only when thinking of the 'nothing' of 'making nothing' can we think of time as beginning and ending, as surrounded by nothingness. ${ }^{24}$ The nothingness and absolute stillness of eternity accentuates the movement and transitoriness of time $\mathrm{e}^{25}$ and the experience of time as transition. Eternity is the precedence of time and therefore its superior. Eternity is a never-ending present and as such it is before all past time and after all future time. Years are all present at once because in eternity they are at a permanent standstill, atemporal, not passing away and thus, eternity is qualitatively and quantitatively surpassing time (Ricoeur [1983] 1990:25-26).

\section{Concluding remarks: The impasse of time: In need of emplotment}

Philosophers like Bergson and Benjamin try to find a new temporality. Ricoeur, however, wants to maintain a temporality with an Augustinian extension and diachronic thrust (Jansen 2015:22). According to Carter (2011:302) Augustine's most extended discussion of time does not occur in his Confessiones but in his later De Musica, suggesting Ricoeur's analysis of Augustine's views on time may be somewhat limited. Nevertheless, the main aporias of time are sufficiently regarded by Ricoeur.

Ricoeur's following idea to incorporate emplotment in the understanding of time is a necessary addition and will be discussed in a follow-up paper. Suffice it to say that it is not a movement away from phenomenology, but an addition to phenomenology. In this regard, the deficiency Ricoeur senses in the phenomenological approach is aptly illustrated by Bennett. Regarding memory, Bennett (2004) describes it as a process of constructing, as 'a trying-to-make-sense'. He refers to a comment by Tobias Wolff in the New York Times on two different interpretations of the same event:

Memory is a storyteller, and like all storytellers it imposes form on the raw mass of experience. It creates shape and meaning by emphasizing some things and leaving others out. It finds connections between events, suggests cause and effect ... (p. 173)

This narrative character of humanity is a consequence of human finitude. Primal finitude consists in perspective or point of view, which is always limited or finite in contrast to the infinite potential points of view, emphasised further by our ineptitude to fully express our viewpoint in

23.The view that time did not exist before creation is also proposed in De Civitate Dei,11.6'... while in eternity there is no change, who does not see that there could have been no time had not some creature been made, which by some motion could give birth to change ...' (Augustine in Humphries 2009:79; Augustinus Hipponensis [426] 2012)?

24.Augustine proposed that God made time (Augustinus Hipponensis [401] 2012) thus time is ontologically dependent on God (Humphries 2009:79).

25.'We cannot truly say that time exists except in the sense that it tends towards non existence' (Augustinus Hipponensis [401] 2012 Book XI). The fleeting movement o time is that of passing into and out of existence (Humphries 2009:84). language (Du Toit 2011:6). Ricoeur ([1960] 2002: 40-41) suggests transcendental imagination as a synthesis linking understanding and sensual perception that leads to selftranscendence as an ongoing process (Ricoeur 1994:115-139) and therefore as a personal story (narrative). This also relates to the correlation between bodily perception of time and the formation of personal identity (Atkins 2000:344).

Viewed in this way, Ricoeur's acceptance of the limitations of phenomology regarding the understanding of time and the expansion of his understanding to include emplotment is logical and necessary. This does not render his phenomenology, nor his proof of the aporetic nature of time, less valuable. To illustrate the point: Ricoeur ([1983] (1990) argues the limitations of phenomenology from the Kantian thesis that time cannot be directly observed and is therefore properly invisible. He concludes aptly that:

... the endless aporias of the phenomenology of time will be the price we have to pay for each and every attempt to make time itself appear, which is the ambition that defines the phenomenology of time as pure phenomenology (pp. 83-84).

Ricoeur then uses the Husserlian analysis of internal time consciousness (Husserl 1966) as counterexample to his thesis on the aporetic character of a phenomenology of time. He regards the proof of the aporetic nature of temporality as necessary for his thesis that the poetics of narrativity responds and corresponds to the aporetics of temporality (Ricoeur [1983] 1990:83-84).

Finally, the need for emplotment is illustrated by the concept of 'narrated time' necessitated by the narrating of history. Ricoeur argues that in the threefold present, we seem to inhabit the past, suggesting that the temporality we inhabit is 'narrated time', or the 'third time' of narrativity as a time of volition and preoccupation intelligible only in narrative terms. It is called a 'third time' because it stands apart from Aristotle's cosmic time ('time of the world') and Augustine's phenomenological 'time of the soul'. It is 'narrated time' as it continues the time of earlier generations and cultures in terms of their stories (Dowling 2010:149). Thus, emplotment is the next and logical expansion of Ricoeur's understanding of time.

\section{Acknowledgements Competing interests}

The author declares that he has no financial or personal relationships which may have inappropriately influenced him in writing this article.

\section{References}

Atkins, K., 2000, 'Personal identity and the importance of one's own body: A response to Derek Parfit', International Journal of Philosophical Studies 8(3), 329-349. https://doi.org/10.1080/096725500750039309

Atkins, K., 2002, 'Ricoeur on objectivity: Between phenomenology and the natural sciences,' Philosophy Today (Winter) 384-395. https://doi.org/10.5840/philtoday 200246425

Augustinus Hipponensis, A., [391] 1938, De Musica libri sex, The Fathers of the Church, 4th edn., transl. R.C. Taliaferro, The Classic's of the St. John's Program, Annapolis, MD. 
Augustinus Hipponensis, A., [401] 2012, Confessions, Kindle edn., vol. XI, transl. E.B. Pusey, Amazon, Seattle, WA.

Augustinus Hipponensis, A., [426] 2012, The city of God, transl. W. Babcock, Hyde Park, New City Press, New York.

Bennett, J., 2004, 'Time in human experience,' Philosophy 79(2), 165-183. https://doi org/10.1017/S0031819104000221

Carter, J.W., 2011, 'St. Augustine on time, time numbers, and enduring objects,' Vivarium 49, 301-323. https://doi.org/10.1163/156853411X606374

Dictionary.com Unabridged, 2011, viewed 06 June 2016, from http://www. dictionary.com/browse/aporia

Dowling, W.C., 2010, 'Paul Ricoeur's poetics of history,' Raritan 29(4), 149-165.

Dowling, W.C., 2011, Ricoeur on time and narrative, Kindle edn., University of Notre Dame Press, Notre Dame, IN.

Du Toit, C., 2011, 'Self-transcendence and Eros: The human condition between desire and the infinite,' HTS Theological Studies 67(3), Art. \#944, 1-12.

Heidegger, M., [1927] 1996, Being and time, transl. J. Stambaugh, State University of New York Press, New York.

Humphries, T.L., 2009, 'Distentio Animi: Praesens temporis, imago aeternitatis' Augustinian Studies 40(1), 75-101. https://doi.org/10.5840/augstudies20094016

Husserl, E., 1966, The phenomenology of internal time consciousness, transl. J. Churchill, Indiana University Press, Bloomington, IN.

Jansen, H., 2015, 'Time, narrative and fiction: The uneasy relationship between Ricoeur and heterogenous temporality', History and Theory 54, 1-24. https://doi. org/10.1111/hith.10738

Kant, I., [1781] 1984, Critique of pure reason, transl. J. Meiklejohn, Everyman's Library, London.

Kohak, E.V., 1966, 'Translator's introduction: The philosophy of Paul Ricoeur,' in P. Ricoeur (ed.), Freedom and nature: The voluntary and the involuntary, pp. xixxxviii, Northwestern University Press, Evanston, IL.

Landridge, D., 2004, 'The hermeneutic phenomenology of Paul Ricoeur. Problems and possibilities for existential-phenomenological psychotherapy,' Existential Analysis 15(2), 243-255.

Lowe, W.J., 2002, 'Introduction,' in P. Ricoeur (ed.), Fallible man, pp. vii-xxxiii, Fordham University Press, New York.

Malan, G.J., 2016a, 'Mythology, Weltanschauung, symbolic universe and states of consciousness', HTS Teologiese Studies/Theological Studies 72(1), a3243. https:// doi.org/10.4102/hts.v72i1.3243

Malan, G.J., 2016b, 'Combining Ricoeur and Bultmann on myth and demythologizing' HTS Teologiese Studies/Theological Studies 72(3), a3216. https://doi.org/10.4102/ hts.v72i3.3216

Malan, G.J., 2016c, 'Ricoeur on myth and demythologising', HTS Teologiese Studies/ Theological Studies 72(4), a2998. https://doi.org/10.4102/hts.v72i4.2998
Malan, G.J., 2016d, 'Myth as metaphor', HTS Teologiese Studies/Theological Studies 72(4), a3260. https://doi.org/10.4102/hts.v72i4.3260

Manning, L., Cassel, D. \& Cassel, J.-C., 2013, 'St. Augustine's reflections on memory and time and the current concept of subjective time in mental time travel,' Behavioral Sciences 3, 232-243. https://doi.org/10.3390/bs3020232

Meyer-Baer, K., 1953, 'Psychologic and ontologic ideas in Augustine's de Musica,' The Journal of Aesthetics and Art Criticism 11(3), 224-230. https://doi.org/10.2307/ 426761

Nabert, J., 1943, Elements pour une ethique, Aubier, Paris.

Nordlund, T., 2015, 'The physics of Augustine: The matter of time, change and an unchanging God,' Religions 6, 221-244. https://doi.org/10.3390/rel6010221

Pellauer, D., 2007, Ricoeur. A guide for the perplexed, Continuum, New York.

Phenomenology Online. A resource for phenomenological enquiry, 2011, viewed 6 June 2016, from http://www.phenomenologyonline.com/enquiry/methodology/ reductio/eidetic-reduction/

Pinterest.com, viewed 22 September 2016, from https://za.pinterest.com/ $\mathrm{pin} / 115123334194644727$

Pinterest.com, viewed 22 September 2016, from https://za.pinterest.com/ $\mathrm{pin} / 429812358161784465 /$

Rasmussen, D.M., 2007, 'Preserving the eidetic moment: Reflections on the work of Paul Ricoeur', Research in Phenomenology 37, 195-202. https://doi.org/10.1163/ 156916407 X185647

Ricoeur, P., [1950] 1966, Freedom and nature: The voluntary and the involuntary, transl. E.V. Kohak, Northwestern University Press, Evanston, IL.

Ricoeur, P., [1960] 2002, Fallible man, 6th edn., Fordham University Press, New York.

Ricoeur, P., 1981, 'The metaphorical process as cognition, imagination, and feeling,' in M. Johnson (ed.), Philosophical perspectives on metaphor, pp. 228-247, University of Minnesota Press, Minneapolis, MN.

Ricoeur, P., [1983] 1990, Time and narrative, vol. 1, transl. K. McLaughlin \& D. Pellauer, University of Chicago Press, Chicago, IL.

Ricoeur, P., [1984] 1990, Time and narrative, vol. 2, transl. K. McLaughlin \& D. Pellauer, University of Chicago Press, Chicago, IL.

Ricoeur, P., [1985] 1990, Time and narrative, vol. 3, transl. K. McLaughlin \& D. Pellauer, University of Chicago, Chicago, IL.

Ricoeur, P., 1994, Oneself as another, University of Chicago Press, Chicago, IL.

Simms, K., 2002, Paul Ricoeur, Taylor \& Francis, Oxford.

Stiver, D.R., 2012, Ricoeur and theology, Bloomsbury T\&T Clark, New York.

Thiselton, A.C., 2006, Thiselton on hermeneutics. Collected works with new essays, Eerdmans, Grand Rapids, MI.

Verhoef, A. \& Van der Merwe, W., 2015, 'Paul Ricoeur se begrip van transendensie met betrekking tot tyd en narratief,' LitNet Akademies 2(12), 196-210. 